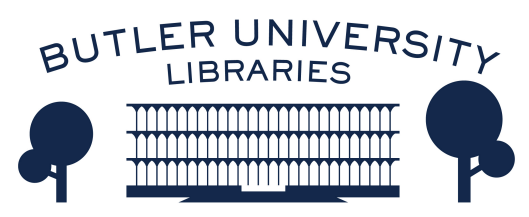

Journal of Hindu-Christian Studies

Volume 23

Article 20

January 2010

\title{
Book Review: "The Founder of Hare Krishnas as Seen by Devotees: A Cognitive Study of Religious Charisma"
}

Kiyokazu Okita

Follow this and additional works at: https://digitalcommons.butler.edu/jhcs

Part of the Religion Commons

\section{Recommended Citation}

Okita, Kiyokazu (2010) "Book Review: "The Founder of Hare Krishnas as Seen by Devotees: A Cognitive Study of Religious Charisma"," Journal of Hindu-Christian Studies: Vol. 23, Article 20.

Available at: https://doi.org/10.7825/2164-6279.1472

The Journal of Hindu-Christian Studies is a publication of the Society for Hindu-Christian Studies. The digital version is made available by Digital Commons @ Butler University. For questions about the Journal or the Society, please contact cbauman@butler.edu. For more information about Digital Commons @ Butler University, please contact digitalscholarship@butler.edu. 


\section{The Founder of the Hare Krishnas as Seen by Devotees: A Cognitive Study of Religious Charisma. Kimmo Ketola. Leiden, Boston: Brill, 2008, pp. xiii, 234.}

ON May $16^{\text {th }} 2010 \mathrm{CNN}$ published an article which, alongside figures such as Ronald Reagan, mentioned A. C. Bhaktivedanta Swami, the founder of the International Society for Krishna Consciousness (i.e. ISKCON, also widely known as the Hare Krishna movement) as one among "Famous folks launched careers after 50". At the age of 69 Swami left India for the first time and moved to the United States to propagate the message of Caitanya (1486-1534), a saint from Bengal. When he arrived in the States in 1965 he was practically penniless. By the time he died, in 1977, his movement boasted "more than hundred ashramas, schools, temples, institutes and farm communities" (Prabhupada 1982 [1970]: 406).

Such a staggering 'spiritual' success story led scholars of religion and sociology to explore the reasons for the Swami's achievement. Previous researches on ISKCON, such as J. Stillson Judah's Hare Krishna and the Counterculture, tended to attribute the movement's success to its social context of the $60 \mathrm{~s}$. In contrast, Kimmo Ketola tackles this question by analyzing the origins of the Swami's charisma from the perspective of the cognitive science of religion. The author argues that the primary sources of the Swami's charisma should be sought in a pan-human psychological mechanism.

The first chapter of Ketola's book lays the theoretical foundation. The author first summarizes Max Weber's two theories of charisma, then discusses the cognitive aspects of these two theories analyzed by Pascal Boyer and Harvey Whitehouse. Based on the theoretical framework laid down in the chapter, the following seven chapters deal with various aspects of the Swami's charisma. The second chapter summarizes the theological teaching concerning the guru. Applying Whiteman's scheme, Ketola concludes that the mode of religiosity in ISKCON is clearly doctrinal. In the third chapter, however, the author discovers that the imagistic elements in Whiteman's scheme are also found in the movement, exemplified by the experience of the devotees during their participation in daily ritual. In the fourth chapter the author argues that the ideas of purity and hierarchy cultivated in the temple life condition the devotees' psychomechanism to perceive a guru in terms of authority and charisma. Chapters five through seven examine devotees' perception of the Swami in terms of Erving Goffman's frame violation theory. Ketola argues that the Swami's behavior, which violated the followers' expectations, was the main source of his charisma. The eighth chapter examines instances such as the Swami's lack of knowledge in a certain field, and his illness, which appear to go against his charisma. The author observes the persistence in the followers' discourse of the Swami's charisma despite these seemingly adversary situations. The final chapter sums up the preceding chapters.

In the book there are some misleading statements about the notion of the guru. For example, following the Weberian scheme, the author describes gurus as teachers of ethics, who perpetuate the tradition based on their acquired knowledge. They are contrasted with prophets who break up with the tradition based on personally revealed knowledge (p. 25). The Hindu gurus are the perpetuators of the tradition in the sense that many of them are within the chain of the teacher-disciple successions, and their teachings are often based on the traditional scriptures. However some of them do break up with their teachers and develop radically new perspectives. Great medieval theologians such as Ramanuja (1017-1137) and Madhva (1238-1317) rejected their respective teachers (Carman 1981[1974]: 29; Sharma 2000: 76), and developed their own schools. More importantly, gurus not " only have the acquired knowledge about the ultimate reality, but they are also supposed to have realized the truth. The Bhagavadgita 4.34 describes gurus as 'the seers of truth (tattvadarshinas)'. Mere textbook knowledge 
(jnana) is often distinguished from realized knowledge (vijnana), which gurus need to possess. Therefore Hindu gurus cannot be categorized neatly according to the Weberian scheme: they possess both the acquired knowledge, which belongs to the teachers of ethics, and the personally revealed knowledge, which belongs to prophets.

Another shortcoming of Ketola's book is that there is no discussion of the historical development of Gaudiya Vaishnavism to which ISKCON belongs. Following Whitehouse's categorization, the author considers the mode of ISKCON's religiosity doctrinal (Ch. 2 especially). Historically speaking, however, the Gaudiya tradition is mostly known for its imagistic mode of religiosity. The descriptions of ecstasy such as fainting, profuse crying and bursting into laughter are abundant in the hagiographies of Caitanya. According to Rupa Goswami (1489-1564), one of the founding fathers of Gaudiya theology, these symptoms are the results of intense feeling of separation from God. In fact, all Gaudiya ritual practices such as chanting and image worship are intended for the cultivation of one's feeling (rasa) toward God. That the religious mode of such a group might be considered imagistic in Whitehouse's scheme is well supported by Joseph O'Connell's 'observation that the Gaudiyas traditionally did not accomplish "hard institutionalization" (2004). The promotion of the more doctrinal mode of religiosity within the Gaudiya tradition began only with Bhaktisiddhanta Sarasvati (1874 - 1937), the guru of Bhaktivedanta Swami, who was responding to the colonial authority's and the British missionary's criticism against the tradition. The doctrinal mode of religiosity is prevalent in ISKCON, since the Swami followed his guru's approach. Had the author kept this historical development in mind, he would not have been surprised to find the imagistic elements in the daily ritual practice in the ISKCON temples (see his discussion in the third chapter).
Nevertheless, The Founder of the Hare Krishnas as Seen by Devotees is a well-rounded research on Bhaktivedanta Swami and ISKCON. The author admirably combines a thorough study of the Swami's and his followers' writings with an extensive participant observation conducted mainly in Finland. What is more, this study is innovative in that it approaches the subject from a cognitive perspective, which had not been done previously in relation to the study of ISKCON. This approach is particularly illuminating when the author's analysis in the eighth chapter reveals the intriguing psycho-mechanism of religious believers who are forced to reconcile the authority of a charismatic guru with his 'imperfections'. The book is suited for those who are interested in the sociology of religion, modern religious movements, as well as Indic religions in general.

Note

1 http:/edition.cnn.com/2010/LIVING/worklife/ 05/16/mf.famous.career.after.50/index.html?iref= allsearch

Bibliography

Carman, John (1981[1974]). The Theology of Ramanuja: An Essay in Interreligious Understanding (Bombay: Ananthacharya Indological Research Institute)

Sharma, B. N. K. (2000 [1961]). History of the Dvaita School of Vedanta and its Literature (Delhi: Motilal Banarsidass)

O'Connell, Joseph T. (2004). Institutionalizing Prema-bhakti

(www.gaudiyadiscussions.com/topic_1446.ht $\mathrm{ml})$

Prabhupada, A. C. Bhakttivedanta Swami. (1982 [1970]) The Nectar of Devotion. (Los Angeles: The Bhaktivedanta Book Trust)

Kiyokazu Okita

University of Florida

\section{India and the Indianness of Christianity: Essays on Understanding- - Historical, Theological, and Bibliographical- in Honor of Robert Eric Frykenberg.}

